\title{
EXHALED AND PLASMA NITRITE: a comparative study among healthy, cirrhotic and liver transplant patients
}

\author{
Viviane S AUGUSTO, Alfredo J RODRIGUES, \\ Ana Paula C SILVEIRA, Orlando de CASTRO E SILVA JR, \\ Enio David MENTE and Paulo Roberto B EVORA
}

\begin{abstract}
Context - There is a relative lack of studies about exhaled nitrite $\left(\mathrm{NO}_{2}^{-}\right)$concentrations in cirrhotic and transplanted patients Objective - Verify possible differences and correlations between the levels of $\mathrm{NO}_{2}^{-}$, measured in plasma and exhaled breath condensate collected from patients with cirrhosis and liver transplant. Method - Sixty adult male patients, aged between 27 and 67 years, were subdivided into three groups: a control group comprised of 15 healthy volunteers, a cirrhosis group composed of 15 volunteers, and a transplant group comprised of 30 volunteers. The $\mathrm{NO}_{2}^{-}$concentrations were measured by chemiluminescence. Results - 1) The analysis of plasma $\mathrm{NO}_{2}^{-}$held among the three groups showed no statistical significance. 2) The comparison between cirrhotic and control groups, control and transplanted and cirrhotic and transplanted was not statistically significant. 3) The measurements performed on of $\mathrm{NO}_{2}$ - exhaled breath condensate among the three groups showed no statistical difference. 4) When comparing the control group samples and cirrhotic, control and transplanted and cirrhotic and transplanted, there was no significant changes in the concentrations of $\mathrm{NO}_{2}^{-}$. Conclusion - No correlations were found between plasma and exhaled $\mathrm{NO}_{2}^{-}$, suggesting that the exhaled $\mathrm{NO}$ is more reflective of local respiratory NO release than the systemic circulation.
\end{abstract}

HEADINGS - Liver transplantation. Liver cirrhosis. Nitric oxide, diagnostic use.

\section{INTRODUCTION}

The increase in exhaled NO production has been reported in patients with advanced cirrhosis, where it is exhaled NO associated with systemic circulatory disorders $^{(15)}$. Patients with liver cirrhosis often have several systemic hemodynamic disturbances, including hypotension, low systemic vascular resistance and reduced sensitivity to vasoconstrictors. With the progression of cirrhosis, continues to decrease vascular resistance, and low splanchnic blood pressure can lead to secondary disorders in kidney, liver blood flow and ascites. The precise mechanisms of these hemodynamic changes are not well understood. Excessive production of vasodilators such as prostacyclin, bradykinin, substance $P$ and atrial natriuretic peptide, has been proposed, but there is no evidence that these are involved vasodilators ${ }^{(12)}$.

There is a relative lack of studies on liver disease changes in exhaled nitrite $\left(\mathrm{NO}_{2}^{-}\right)$concentrations, a marker of injury, following liver transplantation. In this context, investigations on how exhaled NO concentrations vary in cirrhotic and transplanted patients will certainly contribute to new clinical findings. It is worth mentioning that exhaled NO expresses microcirculatory phenomena better than the measurement of $\mathrm{NO}_{2}^{-}$levels in plasma samples collected from the pulmonary artery. Hence, assessment of exhaled NO may be more representative of vasoreactvity in the case of pulmonary hypertension. The initial hypothesis considered the possibility of hepatopulmonary syndrome (HPS), 33\% of the population, which evolves with varying degrees of pulmonary hypertension caused by microvasculature disease, which makes the $\mathrm{NO}_{2}{ }^{-}$vented a possible biomarker being tested in patients with liver disease. Therefore, the aim of this study was to verify whether there are differences and correlations between the levels of $\mathrm{NO}_{2}^{-}$, measured in plasma and exhaled breath condensate (EBC) collected from patients with cirrhosis and liver transplant.

\section{METHOD}

This study was approved by the Ethics Committee of the Hospital of the Faculty of Medicine of Ribeirão Preto of the University of São Paulo - FMRPUSP.

The study population included males between 27 and 67 years of age. The first group, control group

Declared conflict of interest of all authors: none

Departamento de Cirurgia e Anatomia, Faculdade de Medicina de Ribeirão Preto, Universidade de São Paulo, SP, Brasil.

Correspondence: Paulo Roberto B Evora. Rua Rui Barbosa, 367, ap. 15 - 14015-120, Ribeirão Preto, SP, Brasil. E-mail: prbevora@gmail.com 
(CG), was comprised of 15 healthy volunteers with a mean age $37.13 \pm 8.95$ years ( $13.333 \%$ ex-smokers). The second group, designated cirrhosis group $(\mathrm{CiG})$, was composed of 15 cirrhotic subjects with a mean age of $53.40 \pm 9.75$ years (Table 1), and the third group (transplant group, or TxG) was composed of 30 subjects with a mean age of $54 \pm 7.18$ years (Table 2).

Fifteen healthy subjects without clinical criteria for cirrhosis (ascites, jaundice, and encephalopathy) were selected for the CG. The volunteers involved in the study were not current smokers, and they were not taking medications that could interfere with measurements of biomarkers of oxidative stress. The cirrhotic group was composed of 15 individuals from the liver transplant list, with clinical, laboratory, and liver biopsy findings suggestive of cirrhosis, with or without HPS. The transplanted group consisted of 30 individuals, who were at least 3 months status, post liver transplant performed at the FMRPUSP.

EBC and Blood samples were collected from a peripheral vein in the morning and transported on ice at $-20^{\circ} \mathrm{C}$. These samples were placed first in a bath set at $37^{\circ} \mathrm{C}$ and then centrifuged in a common centrifuge at 3,000 rpm for 10 minutes to obtain serum. All samples were stored in a freezer at $-70^{\circ} \mathrm{C}$ for later dosing. The EBC collector device (Figure 1) was mounted in polystyrene box, and a mouth adaptor was added to the circuit, in order to aid patients in breathing in the tidal volume (TV). After correct placement of each circuit (mouth adaptor, plastic tubes, and Eppendorf/1.5 mL), the glass collector was positioned in the center of the polystyrene box which was filled with crushed ice. Care was taken so as not to allow direct contact between the two types of ice, and the measured temperature was around $-10^{\circ} \mathrm{C}$. Disinfection of devices and materials was accomplished with water and

TABLE 1. Profile of the cirrhotic volunteers (cirrhosis group - CiG)

\begin{tabular}{lccc}
\hline Cirrhosis Etiology & $(\%)$ & HPS $(\%)$ & Tabagism $(\%)$ \\
\hline Alcohol & 33.33 & 33.00 & $76.67(\mathrm{non})$ \\
Álcohol/HCC & 13.33 & & $23.33(\mathrm{ex})$ \\
Cryptogenic & 20.00 & & \\
Virus C/Alcohol & 6,67 & & \\
Virus C/ HCC & 13.33 & & \\
Virus B/ HCC & 6.67 & & \\
Virus B/A/ Álcool & 6.67 & & \\
\hline
\end{tabular}

HPS: hepatopulmonary syndrome; HCC: hepatocellular carcinoma

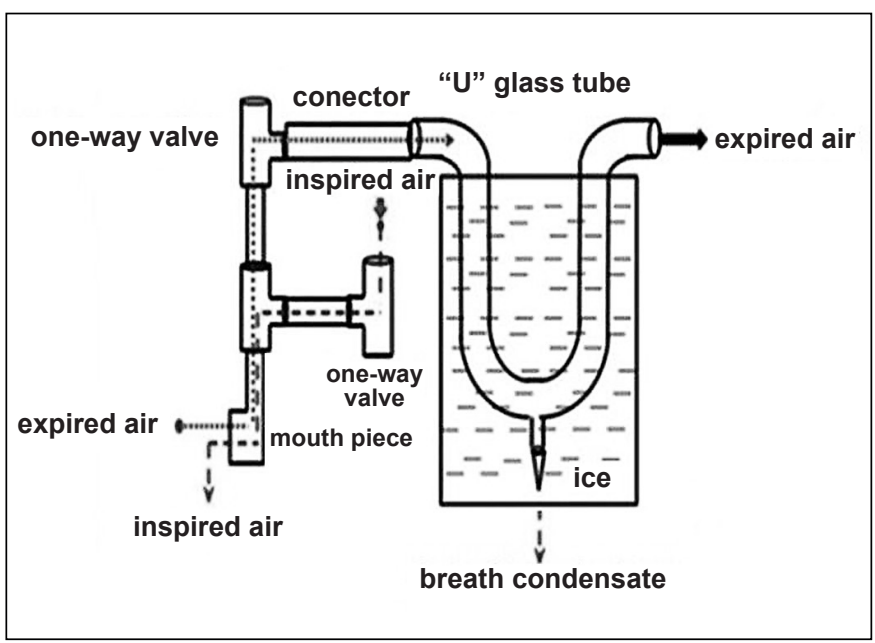

FIGURE 1. Scheme of the apparatus for collecting exhaled breath condensate (EBC)

neutral liquid detergent Extran MA O2 (Merck), followed by rinsing with tap water and Milli - Q water, and drying with medical grade compressed air. To minimize saliva contamination, room air breathing volunteers were asked to rinse their mouth prior the EBC collection. They were instructed to breathe in the TV through the piece adapted to the mouth by closing the lips around it. A calm respiratory pattern was requested during sampling, which lasted 10 minutes. For measurement of plasma EBC levels, $1.5 \mathrm{~mL}$ blood samples were collected through a peripheral venous access preoperatively, and through a central venous access postoperatively. The blood sample was placed in a standard collection tube (BD Vacutainer K2 EDTA) containing $0.08 \mathrm{~mL}$ heparin, transported on ice $\left(-20^{\circ} \mathrm{C}\right)$, and centrifuged at 5,000 rpm for 10 minutes, at $4^{\circ} \mathrm{C}$. The plasma was deproteinated and stored at $-70^{\circ} \mathrm{C}$ for later $\mathrm{NO}_{2}^{-}$level measurement. The plasma and $\mathrm{EBC}$ concentrations of $\mathrm{NO}_{2}^{-}$were performed by chemiluminescence (Nitric Oxide Analyzer, 280i, brandSIEVERS-Sievers NOA) ${ }^{(2,3,13)}$. The data were presented as mean \pm standard deviation. To compare groups of data dosages of plasma and $\mathrm{EBC} \mathrm{NO}_{2}^{-}$, one-way analysis of variance (one-way ANOVA) with Games-Howell post-test were used. Correlations were calculated by the Kendall's Tau-b test. Differences were considered statistically significant when $P<0.05$. All analyses were performed with the aid of SPSS 15.0 (SPSS Inc, Chicago, IL, USA).

TABLE 2. Profile of the liver transplanted volunteers (transplant group - TxG)

\begin{tabular}{lccccc}
\hline Cirrhosis Etiology & $(\%)$ & Immunosuppressive & $(\%)$ & Hepatitis B or C Treatment (\%) & Tabagism $(\%)$ \\
\hline Alcohol & 40.00 & Tacrolimus & 36.67 & 13.33 Hepatite C & $63.33($ non) \\
Cryptogenic & 6.67 & Cyclosporine & 6.67 & 6.67 Hepatite B \\
Virus C/Alcohol & 6.67 & Tacrolimus/Mycophenolate & 23.33 & & \\
Virus C/ HCC & 16.67 & Cyclosporine/Mycophenolate & 10.00 & \\
Virus B & 6.67 & Sirolimus/Mycophenolate & 20.00 & \\
Virus C & 26.67 & Mycophenolate & 3.33 & \\
\hline
\end{tabular}

HCC: hepatocellular carcinoma 


\section{RESULTS}

Differences were observed among the age of the control group (37.13 \pm 8.95 years) and the age of cirrhotic $(53.40 \pm 9.75$ years) and transplanted ( $54 \pm 7.18$ years). There was no difference in age between the groups of cirrhotic patients and transplanted.

The analysis of samples of plasma $\mathrm{NO}_{2}^{-}$held among the three groups $(\mathrm{CG}=9,02 \pm 10,54 ; \mathrm{CiG}=3,97 \pm 2,64 ; \mathrm{TxG}=$ $4,92 \pm 1,44)$, showed no statistical significance $(P=0.561)$. The comparison between cirrhotic and control groups $(P=0.534)$, control and transplanted $(P=0.934)$ and cirrhotic and transplanted $(P=0.594)$ was not statistically significant (Figure 2$)$.

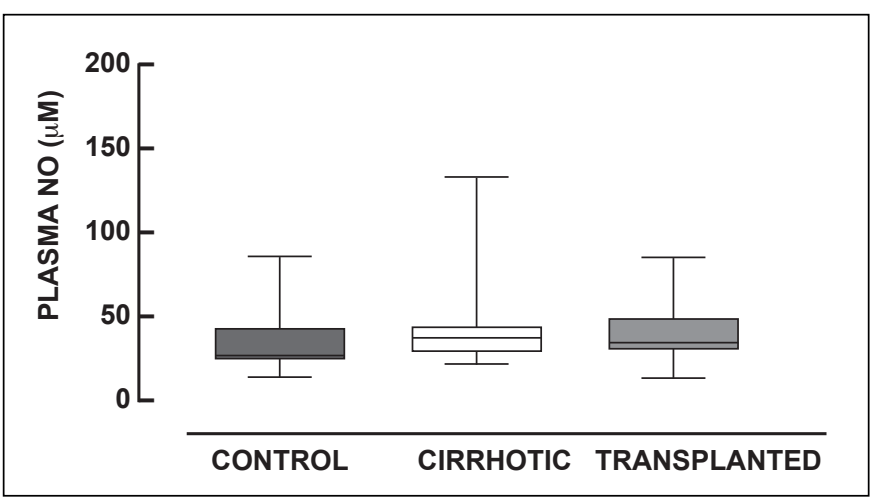

FIGURE 2. Dosage of plasma $\mathrm{NO}_{2}$ - among the control $(\mathrm{n}=15)$, cirrhotic $(\mathrm{n}=15)$ and transplanted patients $(\mathrm{n}=15)$. One-way analysis of variance (one-way ANOVA) with Games-Howell post-test were used. Data were considered statistically significant when $P<0.05$

The measurements performed on samples of $\mathrm{NO}_{2}{ }^{-} \mathrm{EBC}$ among the three groups, control, cirrhotic and transplanted $(\mathrm{CG}=36,97 \pm 21,83 ; \mathrm{CiG}=47,95 \pm 32,71 ; \mathrm{TxG}=39,18 \pm 14,99)$ results showed no statistical difference $(P=0.163)$. However, there was a greater average value when analyzing $\mathrm{NO}_{2}{ }_{2}^{-}$control group samples. When comparing the control group samples and cirrhotic $(P=0.202)$, control and transplanted $(P=0.321)$ and cirrhotic and transplanted $(P=0.411)$, there was no significant changes in the concentrations of $\mathrm{NO}_{2}-$ (Figure 3$)$.

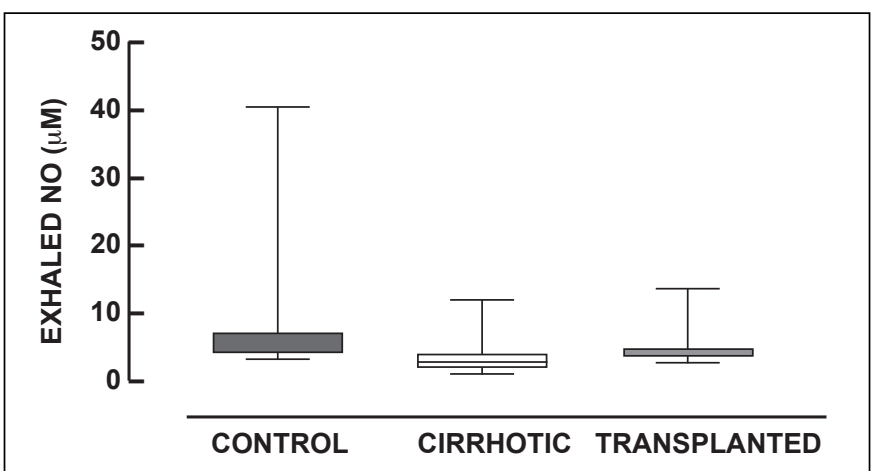

FIGURE 3. Dosage of exhaled EBC $\mathrm{NO}^{-}$among the control $(\mathrm{n}=15)$, cirrhotic $(n=15)$ and transplanted patients $(n=15)$. One-way analysis of variance (one-way ANOVA) with Games-Howell post-test were used. Data were considered statistically significant when $P<0.05$
No correlations were found between plasma and exhaled $\mathrm{NO}_{2}^{-}$- calculated by the Kendall's Tau-b test.

\section{DISCUSSION}

In cirrhosis, decreased hepatic arterial and venous infusion may decrease of portal blood flow as a result of portal hypertension and blood flow may decrease due to impairment of autoregulation. However, patients with cirrhosis changes may be due to the systemic circulation and arteriovenous shunt splanchnic blood flow reduction. The reduction in hepatic perfusion becomes cirrhotic liver more susceptible to the effects of hypoxemia and hypotension during surgery ${ }^{(8)}$.

Patients with advanced liver disease have progressive pulmonary and splanchnic vasodilatation. This leads to a hyperdynamic circulatory state, which is associated with a high cardiac index (CI) and an increase of fluid in response to vasodilatation. Decreased arterial oxygenation, ranging from increased alveolar-arterial hypoxemia to severe, is commonly found in patients with cirrhosis. In the absence of obvious mechanical malfunction of the lungs, oxygenation abnormalities may be a consequence of the loss of ventilation-perfusion (V/Q), pulmonary shunt and/or diffusion of oxygen $\left(\mathrm{O}_{2}\right)^{(6)}$.

Vallance and Moncada (1991) hypothesized that NO may be the triggering factor of the hemodynamic changes in patients with liver cirrhosis. High concentrations of circulating endotoxin are often found in patients with cirrhosis who have no clinical evidence of infection ${ }^{(17)}$. So endotoxemia of cirrhosis can directly induce NOS in blood vessels or indirectly through cytokines, leading to increased synthesis and release of NO that may explain the hemodynamic abnormalities.

Sogni et al. showed that exhaled NO levels are increased in Child C cirrhotic patients compared with healthy subjects. The increase in exhaled NO and pulmonary vascular resistance decreased, suggest that increasing endogenous NO could explain the reduction in vascular tone severe cirrhosis ${ }^{(16)}$.

In the evaluation of plasma $\mathrm{NO}_{2}^{-}$observed higher mean values for the cirrhotic group $(47.95 \pm 32.71)$ when compared with control groups $(36.97 \pm 21.83)$ and transplanted (39.18 \pm 14.9$)$. Results of the literature are controversial. High levels of $\mathrm{NO}_{2}{ }^{-}$and $\mathrm{NO}_{3}{ }^{-}$are found in patients with cirrhosis and chronic liver disease. Levels of $\mathrm{NO}_{2}^{-}$and $\mathrm{NO}_{3}^{-}$has been correlated with disease stage, considered as resulting from the hyperdynamic circulation often induced by portal hypertension. On the other hand, Becker et al. found a significant difference in the $\mathrm{NO}_{2}^{-}$and $\mathrm{NO}_{3}{ }^{-}$concentrations of from transplant patients and healthy individuals during the phase prior anesthesia to the time of reperfusion ${ }^{(4)}$. Lluch et al. found that the plasma concentrations of NO were significantly higher in decompensated cirrhosis compared to compensated cirrhotic patients and control subjects, but no difference in the comparison between controls and compensated cirrhotic patients. In contrast, in this study, higher mean values of $\mathrm{NO}_{2}^{-}$plasma were found to cirrhotic group compared to the control groups and transplanted ${ }^{(10)}$. The 
differences between the studies published in the literature are probably associated with the clinical stages of the disease, number of patients enrolled, patients' age, the EBC collection methodology, and time of transplantation. In cases allocated in the present study it was observed an age markedly lower of the patients in the control group, the method of collecting the EBC was an original adaptation, cirrhotic patients were clinically stable, and the time of liver transplantation was more than one year.

The concentration of NO in exhaled air is decreased in patients after lung transplantation and in patients with acute respiratory distress syndrome (ARDS), but in relation to cardiac surgery, cirrhosis and liver transplant outcomes are being established recently ${ }^{(1,9,11)}$. In this study, the EBC dosages of $\mathrm{NO}_{2}^{-}$among the three groups, control (10.54 \pm 9.02$)$, cirrhotic (3.97 \pm 2.64$)$ and transplanted $(4.92 \pm 1.44)$ revealed no statistically significant results. Surprisingly, we observed a greater control group average value when analyzing the EBC $\mathrm{NO}_{2}{ }^{-}$samples. In addition, no increases were observed in the concentrations of $\mathrm{NO}_{2}^{-}$in exhaled air of patients in the cirrhosis, or in the postoperative period of liver transplantation. Therefore, the exhaled $\mathrm{NO}_{2}^{-}$, in this sample of patients, there was not a reliable biomarker. Rolla et al. found that prior to liver transplant concentration of exhaled NO in cirrhotic patients was higher than in normal controls and after the procedure this concentration decreased and was significantly correlated with the decrease in alveolar-arterial gradient ${ }^{(14)}$. According to Matsumoto et al. the increase in exhaled NO is associated with systemic circulatory disorders in patients with liver cirrhosis ${ }^{(12)}$.

The correlation between plasma and exhaled NO seems unlikely, because of the NO short half-life the presence of oxygen, hemoglobin and reactive oxygen species. However, it has been shown that NO may be preserved in vivo for binding to albumin, transported in this form and released elsewhere ${ }^{(7)}$. In the present study, there was no correlation between plasma $\mathrm{NO}_{2}^{-}$and exhaled, regardless of the group examined. This finding is similar to results found by Biban et al. and Dillon et al., where no correlation between EBC and plasma NO levels were observed. This data may indicate that the exhaled NO, at least in normal conditions, are more reflective of local formation of NO than systemic ${ }^{(5,7)}$.

\section{Study limitation}

Most suitable is the same patients were assessed before and after the transplant, thus avoiding the significant individual variations. The normal group (control) had an average age significantly different from the other groups, which could have influenced the outcome.

\section{CONCLUSION}

The $\mathrm{NO}_{2}^{-}$measurements performed on samples of EBC among the three groups, control, cirrhotic and transplanted results showed no statistical difference. In addition, no correlations were found between plasma and exhaled $\mathrm{NO}_{2}^{-}$, suggesting that the exhaled NO is more reflective of local respiratory NO release than the systemic circulation.

\section{Sources of funding}

Coordenação de Aperfeiçoamento de Pessoal de Nível Superior (CAPES), Fundação de Apoio ao Ensino, Pesquisa e Assistência do Hospital das Clínicas da Faculdade de Medicina de Ribeirão Preto da Universidade de São Paulo (FAEPA), Conselho Nacional de Desenvolvimento Científico e Tecnológico (CNPq).

Augusto VS, Rodrigues AJ, Silveira APC, Castro e Silva Jr. Nitrito exalado e plasmático: um estudo comparativo entre pacientes transplantados saudáveis, cirrose e fígado. Arq Gastroenterol. 2014,51(1):16-20.

RESUMO - Contexto - Observa-se relativa falta de estudos sobre nitrito $\left(\mathrm{NO}_{2}^{-}\right)$exalado como biomarcador de lesão, após transplante de fígado. Objetivo Verificar possíveis diferenças e correlações entre os níveis de nitrito $\left(\mathrm{NO}_{2}^{-}\right)$, medido no plasma e condensado do exalado pulmonar de pacientes com cirrose e transplante de fígado. Método - Sessenta pacientes adultos, masculinos, idades entre 27 e 67 anos, foram divididos em três grupos: grupo controle composto por 15 voluntários saudáveis, grupo cirrose, composto por 15 voluntários e, grupo de transplante, composto por 30 voluntários.

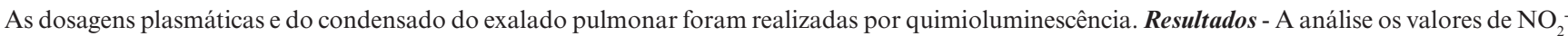
plasmático não mostrou diferença entre os grupos. As comparações entre grupos cirrose e controle, controle e transplantados e cirrose e transplante não foram significativas. As medidas em amostras de condensado do exalado pulmonar entre os três grupos não evidenciaram diferenças estatísticas. Ao comparar as amostras dos grupos controle e cirrótico, controle e transplantado e cirróticos e transplantados, não houve alterações significativas nas concentrações de $\mathrm{NO}_{2}$. Conclusão - Não foram encontradas correlações entre plasma e condensado do exalado pulmonar, sugerindo que o NO exalado reflete mais as condições respiratórias locais de liberação de NO do que a circulação sistêmica.

DESCRITORES - Transplante de fígado. Cirrose hepática. Óxido nítrico, uso diagnóstico. 


\section{REFERENCES}

1. Alexiou C, Tang AT, Sheppard SV, Haw MP, Gibbs R, Smith DC. A prospective randomized study to evaluate the effect of leukodepletion on the rate of alveolar production of exhaled nitric oxide during cardiopulmonary bypass. Ann Thorac Surg. 2004;78:2139-45

2. Arcêncio L, Vento DA, Bassetto S, Evora PR, Rodrigues AJ. Exhaled nitrite/ nitrate levels as a marker of respiratory complications after heart valvesurgery. $\mathrm{J}$ Crit Care. 2013;28:533.e1-7.

3. Augusto Vdos S, Reis GS, Capellini VK, Celotto AC, Rodrigues AJ, Evora PR Nitrite exhaled breath condensate study in patients undergoing cardiopulmonarybypass cardiac surgery. Rev Bras Cir Cardiovasc. 2011;26:15-20.

4. Becker T, Mevius I, de Vries DK, Schaapherder AF, zu Vilsendorf AM, KlempnauerJ, Frölich JC, Tsikas D. The L-arginine/NO pathway in end-stage liver disease and during orthotopic liver and kidney transplantation: biological and analytical ramifications. Nitric Oxide. 2009;20:61-7.

5. Biban P, Zangardi T, Baraldi E, Dussini N, Chiandetti L, Zacchello F. Mixed exhaled nitric oxide and plasma nitrites and nitrates in newborn infants. Life Sci. 2001;68:2789-97.

6. Degano B, Mittaine M, Hervé P, Rami J, Kamar N, Suc B, Rivière D, Rostaing L. Nitric oxide production by the alveolar compartment of the lungs in cirrhoticpatients. Eur Respir J. 2009;34:138-44.

7. Dillon WC, Hampl V, Shultz PJ, Rubins JB, Archer SL. Origins of breath nitric oxide in humans. Chest. 1996;110:930-8.

8. Gelman S, Dillard E, Bradley EL Jr. Hepatic circulation during surgical stress and anesthesia with halothane, isoflurane, or fentanyl. Anesth Analg. 1987;66:936-43.
9. Kövesi T, Szabo A, Royston D, Marczin N. Correlation between pulmonary gas exchange and basal and nitroglycerin (GTN)-induced exhaled nitric oxide (eNO) in patients undergoing cardiac surgery. Vascul Pharmacol. 2005;43:434-40.

10. Lluch P, Torondel B, Medina P, Segarra G, Del Olmo JA, Serra MA, Rodrigo JM. Plasma concentrations of nitric oxide and asymmetric dimethylarginine in human alcoholic cirrhosis. J Hepatol. 2004;41:55-9.

11. Marczin N, Kövesi T, Royston D. Exhaled nitric oxide as a marker of lung injury in coronary artery bypass surgery. Br J Anaesth. 2003;90:101-4.

12. Matsumoto A, Ogura K, Hirata Y, Kakoki M, Watanabe F, Takenaka K, Shiratori Y, Momomura S, Omata M. Increased nitric oxide in the exhaled air of patients with decompensated liver cirrhosis. Ann Intern Med. 1995;123:110-3.

13. Reis GS, Augusto Vdos S, Souza ME, Baldo CF, Rodrigues AJ, Evora PR. Exhaled breath condensate collection for nitrite dosage: a safe and low cost adaptation. Acta Cir Bras. 2010;25:206-13.

14. Rolla G, Brussino L, Colagrande P, Scappaticci E, Morello M, Bergerone S, Ottobrelli A, Cerutti E, Polizzi S, Bucca C. Exhaled nitric oxide and impaired oxygenation in cirrhotic patients before and after liver transplantation. Ann Intern Med. 1998;129:375-8.

15. Rolla G, Brussino L, Dutto L, Ottobrelli A, Bucca C. Smoking and hypoxemia caused by hepatopulmonary syndrome before and after liver transplantation. Hepatology. 2001;34:430-1.

16. Sogni P, Garnier P, Gadano A, Moreau R, Dall'Ava-Santucci J, Dinh-XuanAT, Lebrec D. Endogenous pulmonary nitric oxide production measured from exhaled air is increased in patients with severe cirrhosis. J Hepatol. 1995;23:471-3.

17. Vallance P, Moncada S. Hyperdynamic circulation in cirrhosis: a role fornitric oxide? Lancet. 1991;337:776-8 